\title{
HETEROGENOUS OLDER \\ WORKERS: OLDER WOMEN \\ "OPTING OUT" IN NEW \\ DIRECTIONS
}

\author{
Barbara Myers
}

Faculty of Business

AUT University

\begin{abstract}
Studies on older workers suggest that organisations expect to employ older workers in increasing numbers. To date, research focuses on strategy and policy thus contributing to the perception of the older worker as collectively an "issue." Recent research confirms the persistence of some negative stereotyping of the older worker and suggests that increased employment levels for older workers may reflect employer expediency rather than a change in employer attitude.

Anecdotal observations suggest that many older workers faced with expectations to continue paid work into their sixties and seventies, are seeking alternative life paths outside the labour market. Fragmentary commentary suggests that some older women are choosing to undertake an OE or 'self-initiated foreign experience' (SFE), a period of autonomous travel and work in another country.

While there is a nascent career literature on these foreign experiences that suggests that career development is a substantial outcome arising from what appears to be a serendipitous, youthful and carefree endeavour, there has been limited research on the careers of individual older women workers undertaking a SFE.

By reviewing the extant literature on older workers and careers, this paper develops a conceptual framework to better understand the motivations, experiences and outcomes for these older women who exit the labour market and undertake a 'foreign experience' as a catalyst for renewal in life and career development.
\end{abstract}

\section{Introduction}

International research on population trends in the western world suggest that an ageing population is expected to reduce the supply of labour over the next two decades as cohorts of baby boomers exit the labour market (Loretto \& White, 2006). Over the last twenty years employers have held the balance of power in the selection process. However an ageing population suggests that employees may develop a stronger negotiating position as employers struggle to fill positions. (Henkens, Remery \& Schippers. 2008).

Although population ageing is a phenomenom of the western world, the economic, social and cultural context of individual nations varies. In the United kingdom labour market participation rates for the older worker declined in the $80 \mathrm{~s}$ and $90 \mathrm{~s}$ and then limited increase followed in the early years of the $21^{\text {st }}$ century (Whiting, 2005). The U.K. government developed a number of initiatives to extend working lives. These projects were initially conceived to address concerns such as the U.K.'s failure to reach EU employment targets and the need to address the dependency and poverty issues that arise from an early exit from the labour market (Vickerstaff, Cox \& Keen 2003).

As a result of population ageing it is predicted that the European Union will experience a declining labour market particularly after 2010 although the extent of this may vary across individual countries. It is predicted that approximately half of the EU counties will experience a significant decline around 2015 (De Jong \& Edding, 2000). Public policy was devised in the 90 s to address high unemployment levels and encourage early retirement in favour of younger workers in countries such as Belgium, France and Germany. These initiatives have additionally contributed to a shrinking labour market.

Australia is also facing the challenges of population ageing. It is predicted that by 2050 one quarter of the population will be 65 years plus and might expect to live up to another 25 years (Drew, M. \& Drew, 2005). The impact of population ageing on future labour market participation rates has been the subject of several research projects commissioned by the Australian government. The Intergenerational Reports, the Commonwealth Treasury Report (Gruen \& Garbutt, 
2003) and the Productivity Commission (2005) identify a number of pertinent issues. However the key issue identified by all the studies is the continued trend towards early retirement by older workers at a time when employers face a worsening skills shortage.

While the situation in New Zealand is similar in terms of trends in population ageing there are also some factors unique to New Zealand that impact on the trends. Population ageing is occurring at a slightly slower rate than in Europe and current labour market participation rates of older workers (particularly in the older age cohorts of 60 to 64 plus) are generally at the higher end of OECD statistics. The high labour market participation rates of these men and women in the 60 plus age groups can be attributed to public policy changes in superannuation (increasing eligibility to 65 years), the removal of compulsory retirement and changes to the human rights act outlawing age based discrimination (Dunstan and Thomson, 2006). However overall male labour market participation rates have declined over the last 40 years across all age cohorts while female labour market participation rates have steadily risen although they still remain lower than males.

In the last thirty years older workers in the majority of OECD countries have withdrawn from the labour market through early retirement or redundancy in a disproportionate numbers when compared to other age groups. Significant deregulation of industry sectors, technological innovations, organisational restructuring and the globalisation of business production and processes has adversely impacted on these older workers. (Taylor, 2003).

While there are a range of strategies available to address the impact of population ageing on the labour market, most countries in the western world have identified "older workers," as a key alternative supply of labour and the development of public policy to encourage greater levels of labour market participation and reduce levels of early retirement. (OECD, 2001). Australian studies on population ageing and the economy, identified older workers as a vital group to be retained in the labour market (Drew \& Drew, 2005). In New Zealand the Drake white paper and similar studies (Drake, 2005) conclude that strategies of immigration and labour market participation by new entrants alone would not address the predicted shortages arising from population ageing .

It is acknowledged that no one strategy alone can address the predicted shortages in the labour market (Henkens et al, 2008). However current research suggests that in the New Zealand context, initiatives to encourage the retention and recruitment of older workers are fundamental to addressing the labour market issues arising from population ageing (Alpass \& Mortimor, 2007) and potentially more effective than alternative strategies encouraging immigration and higher fertility.

Successful retention and recruitment of older workers has considerable benefits for the individual older worker in terms of independence, well being and social integration and to the government in terms of an active and productive ageing policy. Additionally it offers a viable and alternative source of labour to employers in a time of increasing skill shortages. In an analysis on the impact of the ageing population on the New Zealand labour market, Davey (2006) suggests that (2006, p.197): "forward looking employers may consider a range of options to retain older workers or encourage them to reenter the workforce."

\section{Who is an older worker?}

While it is expected that employers will increasingly look to the older worker to address labour market shortages, there appears to be limited definitional consensus on who is an "older worker."

The OECD definition of an older worker is 55 years (OECD, 2000). More recent OECD data analysis setting 50 as the base line age, suggests some flexibility in the definition of who is an older worker. (Alpass \& Mortimor, 2006).

In the UK there appears to be an emerging consensus that 50 plus defines the age of the older worker. The Joseph Rowntree Foundation research programme on the older worker is called "Transitions after 50," (Hirsch, 2003) while the Department for Work and Pensions (DWP) research evaluations of the New Deal $50+$ programmes (Atkinson and Dewson, 2003) implicitly sets 50 years as the lower age threshold for the older worker.

The Australian Department of Employment and Workplace Relations (DEWR) has identified workers aged 45 plus as "older workers," arguing that these workers face disadvantage in finding employment and offering workers increasing levels of assistance in line with advancing age. The Australian Bureau of Statistics classifies workers aged 45 years and over as "mature workers."

The New Zealand Department of Labour does not stipulate a specific "older worker," age threshold. The department's "45 plus" research project overviewing current research on careers and related matters for unemployed mature workers, implies that 45 is the age that one becomes an "older worker." A discussion paper (Alpass \& Mortimor, 2006) on the ageing workforce and ageing occupations suggests a range of thresholds. The department also produces an annual report on older workers focussing on labour market changes and near term prospects for New Zealanders aged 55 years and over. In contrast a report on older workers (McGregor, 2005) examining employment changes for 50 to 64 year olds over the previous 15 years identifies 50 as the lower threshold for defining an older worker. Statistics New Zealand use the term "mature worker," rather than "older worker," in their Labour market census and 
projections identifying an age range of 45 to 65 years. In a discussion on increasing labour market participation by under-represented groups, Davey (2006) refers to "prime-age women," as 24 to 54 years and by default older workers as 55 years plus.

The organisational perspective on who is an older worker is less generous when employers' perceptions are compared with employees'. Employers tend to consider workers as "older," at an earlier age than individual employees. New Zealand research on the older worker revealed that $62 \%$ of employees consider a worker old at 50 while Australian employers are more generous in their judgement. Sixty-two percent of Australian employers consider 55 to be the benchmark for an older worker. (Steinberg, M., Walley, L., Tyman, R., Donald, K., 1998).

Professional sectors also set thresholds for "older worker" status that may be at variance to other professions. In New Zealand there are serious concerns about the advanced ageing of some professions. (Alpass \& Mortimor, 2007). The public service sector, tertiary teaching, GPs, nurses and midwives have been identified as having high median ages. In contrast the median age and perception of "who is an older worker" in sectors such as advertising and hospitality is much younger.

An individual's perception of who is an older worker is no less confusing. When questioned about the age one becomes an older worker, an individual may answer 45 or 55. When questioned about whether "they" are an older worker, the answer may be quite different. For example they may perceive themselves as productive and effective as a younger worker or even deny they are an older worker. (Myers, 2001). The term "older worker" appears to be an outcome of how an individual compares themselves to others and is constructed in a broader cultural and social context. In addition demographic changes, expectations of a longer life span and powerful media influencers suggesting that 50 is the new 40 , continue to challenge the traditional understanding of the chronological and biological ageing processes.

Research on "who is an older worker" tends to cover a range of 25 years ie from 40 to 65 . A number of difficulties arise from this. For example policies such as retraining, retirement and flexible work may have very different meanings for a 40 year old compared to a 60 year old. It is likely that issues pertaining to health, career development and superannuation will also have different meanings for the various age cohorts. As long as there is wide variation in defining and interpreting who is an older worker, the development of relevant and consistent policy will remain challenging.

\section{Attitudes to Older Workers}

As the implications of population ageing and labour shortages become more urgent so does the need to develop policy that encourages the retention and integration of all age cohorts of the labour market and in particular older workers (Taylor, 2003).

The concept of productive or active ageing i.e continued activity contributes to positive outcomes (Everard, Lach, Fisher \& Baum, 2000) has become an integral part of this issue. Productive ageing literature argues that traditional views of a work/non work dichotomy no longer apply and that social, economic and employment policy need to provide a more inclusive framework that supports the economic wellbeing of the older citizen or older worker thus facilitating contribution rather than dependence in later years (Morrow-Howell, 2000).

While it may be expected that employers will seek to employ older workers, research suggests that employers tend to see older workers as a homogenous group and at times more negatively than positively. While the definition of stereotypes is neutral in intent i.e they are not necessarily positive or negative, stereotypes of older workers can depict them as less productive, less flexible, and more expensive than younger workers (Taylor \& Walker, 2003). A study by MacGregor and Gray (2001) found that older workers themselves perceived a falling off in their effectiveness and efficiency. Alternatively Warr (1994) suggests there is greater variation in levels of effective performance within age cohorts than between them, that older workers are generally as effective as younger workers and although they may be less strong and fast in their activities they bring the advantages of wide experience and expertise (Davy, 2006).

Older workers may be viewed by employers as posing a higher health risk in the workplace and having higher levels of absenteeism than younger workers despite research evidence to the contrary (Turner, 2000). High older worker salaries earned through longer labour market experience are also seen as a major obstacle by employers despite the increasing prevalence of performance and competency based remuneration. (Patrickson and Hartman, 1995)

Contemporary career theory argues that individuals ought to take responsibility for managing their career especially in terms of training and development issues (Arthur \& Rousseau, 1996). Pringle and Mallon (2003) suggest that training and career development planning remain the joint responsibility of the employer and employee. However stereotypes of older workers around issues of training remain a barrier. Older workers are sometimes perceived by employers to be inflexible, unable to adopt to new technology and changing job roles. While international research argues that older workers learn as effectively as other age cohorts provided the training is delivered in an appropriate context and linked to existing skills and experience, employer attitudes towards older workers may mean that they are sometimes excluded (Sterns \& Miklos, 1995) or have reduced access to training and development (Davey, 
2006), even when they have specifically expressed an interest in training (Taylor and Unwin, 2001)

Negative attitudes towards older workers is also apparent in some organisational policy and practice. Older workers are often the first target in organisation restructuring (Lyon, Hallier and Glover, 1998), sometimes with the implicit approval of unions (Duncan, 2003). When faced with such practices the older worker may prefer to withdraw or retire rather than be made redundant (Taylor \& Walker, 1997, Loretto \& White, 2000).

Despite the arguments identifying older workers as a viable source of labour, it appears that even when stereotypes can be proven wrong, the attitudes of some employers' reinforce negative stereotyping of older workers as a homogenous group. That older workers are not valued to the same extent as other age cohorts is evident in the policies and practices of many organisations (Walker and Taylor, 1994). When faced with the imperative of drawing on older workers some go as far to say that employers will not consider them (Henkens et al, 2008). More recently it is suggested that increased labour market participation levels for older workers in New Zealand (and especially those of women.) reflect employer expediency in a strong labour market rather than a fundamental change in employer attitude (Davy, 2006).

\section{A new generation of older women workers..opting out}

The new generation of older workers is moving into a world where the years of employment have been extended. When the parents of current older workers were a similar age they were actively planning for retirement or downsizing employment activity. In contrast, many in the current generation of older workers are considering how best to manage the next 15 to 20 years of their work life in paid employment, working past their three score years and ten.

While there is an extensive literature on older workers in terms of policy and attitudes, there has been limited research on the careers of older workers, and in particular women workers in mid to later life. These women are facing a markedly different future than their foremothers with increased life expectancy, longer career spans, increasing responsibilities inside and outside the home and greater financial responsibilities. While global organisations face critical skills and labour shortages in an ageing labour market, anecdotal evidence suggests the existence of a cohort of women in New Zealand who in the absence of any older female career role models may choose to turn their back on a mainstream career and withdraw from the labour market (Hoffart, 2006, Hepozen, 2008, Shepherd, 2008) and undertake a SelfInitiatied Foreign Experience (SFE), a period of autonomous travel and work in another country (Suutari \& Brewster, 2000; Inkson \& Myers 2003; Vance, 2003).

These women appear to disrupt the view of the marginal and powerless older worker by challenging the male norm of continuous careers through their SFEs. In these actions they simultaneously challenge and upset traditional expectations of older women. What motivates older women workers to take such action? What experiences do they undertake, why and what outcomes if any, do they expect? Is this a fleeting trend, an exceptional and limited phenomenon or is this a radical shift in women's way of being, a new and emerging strand of life development and career theory?

This paper uses a gender lens to explore the relevant literatures that speak to the experiences of individual older women who seek non standard 'foreign experiences' as a catalyst for renewal in life and career development and provide a conceptual framework for an in depth study of older women workers.

\section{Traditional Career Theory}

Early career theory developed around the life stages of the traditional male career experience (Erickson 1968; Super 1957). While the stages were not seen as specifically age related the career was depicted as progressive hierarchical rather than circular (Mirvis and Hall, 1996). The concept of the life cycle and adult development was integrated into the Erickson model based on a study of men (Levinson, Darrow, Klein, Levinson and McKee, 1978), while the later study (Levinson and Levinson, 1996) focussed on women identifying the ongoing tension women face in the gender differentiating roles of homemaker and career women. While the latter went some way towards developing a woman's perspective the model was based on a number of limiting assumptions. Levinson and Levinson's (1996) model continued to conceptualise careers as linear and sequential covering a limited life span and drawing on a homogenous sample.

Building on Levinson et als (1978) work, Bardwick's research on women's career development (1980) highlights the differences between men and women's approach to work. While men identify themselves through their work with an emphasis on "doing and individuation," Barnett argues that women undertake a variety of roles simultaneously that emphasises "being, interdependence and connectedness." While Bardwick also suggests some gender specific life transitions ( for example the development of sexuality and midlife transitions) the research did not address issues re older women in later life and was critiqued for its adherence to a linear framework based on men's career experiences. 


\section{The Development of Women's Career Theory}

Over the last 20 years a body of literature on womens' careers has developed suggesting that womens' careers are more holistic and organic than mens' careers. It is argued that womens' careers encompass aspects of diverse personal experiences and life development while mens' lives are primarily defined by paid work, unpaid work or unemployment. Gallos (1989) argues that male based theories mask the understanding of women's relational way of being. Gutek and Larwood (1987) assert that women's career development ought not to reflect that of men but do not offer a specific model beyond suggesting a tentative theory. A number of studies on womens lives have identified the importance of relationships, connections and achievements (Chodorow, 1976; Giele, 1980). The development literature and the networking literature suggest that there are notable gender differences in the context and nature of relationships. Women emphasise the supportive and empathic nature of connections while men ordain a more instrumental approach to relationships (Umberson et al, 1996).

Within "women's careers," relationships are identified as integral (Gallos, 1989; Wood, 2000;) creating connections with others and the external world. Marshall (1989) conceptualises this relational connectedness as "communion," in contrast to the concept of "agency," (Pringle \& McCulloch Dixon, 2003). While the concepts of agency and communion have contributed to the development of conceptualising careers (Marshall, 1989; Arthur et al, 1999), there has been some disquiet over the dichotomous tendency of womens career theorists to overplay the role of relationships and seamlessness while men's career theorists have emphasised the significance of work.

While aspects of the above models may well be relevant to older women workers who opt out of paid employment to go on an SFE, the theory does not appear to have the flexibility to encapsulate the holistic and wide ranging experiences and transitions of womens life and career development. In more recent years there has been a call to develop a career model that

....has the capacity to embody the emotional. spiritual, physical, psychological as well as the outer achievements of an "objective" career (Pringle \& McCulloch-Dixon 2003, 291)

Pringle and McCulloch Dixon (2003) draw on the work of the early career theorists and previous careers case study research (Arthur et al, 1999) to conceptualise women's career development in a model comprising four facets ie explore, focus, rebalance and revive. In contrast to earlier careers research the model is evolutionary in nature and integrates significant external life changes with internal processes suggesting the four facets may also be a relevant model for exploring the career and life development issues of older women workers who undertake a SFE.
The boundaryless career model (Arthur \& Rousseau, 1996) challenges the traditional concept of careers as a series of linear and progressive steps within one organisation and is central to the models identified as the "intelligent career" (Arthur et al, 1995), the "protean career," (Hall, 1996) and the "post corporate career' (Peiperl and Baruch, 1997). The common themes of these models is the view that careers are the responsibility of the individual to manage rather than the organisation. While some research suggests that the boundaryless model may fit well with women's relational way of being (Fondas, 1996) and allow women to better manage career and life transitions, other research counters this suggesting that careers do not exist without boundaries (Pringle \& Mallon, 2003) and that women may in fact be disadvantaged by the boundaryless career model (Eby, 2001). The intelligent career model suggests that competencies of knowing how, knowing whom and knowing why are essential to success in a boundaryless career. However the transitional nature of womens' careers and in particular the older women workers opting out of the labour market, suggests that while older women workers may have competency in "knowing why" their withdrawal from the labour market may disadvantage them in other respects.

The Kaleidoscope career model (Maniero and Sullivan, 2005) conceptualises an alternative approach to career and life development theory. Cognisant of the different way in which men and women describe their careers, Maniero and Sullivan suggest a new model that accommodates

"career interruptions, employment gaps, top-outs, opt outs, as well as the new values of the current generation," (Maniero, L.A. and Sullivan, S.E. 2005, p108).

Maniero and Sullivan (2005) argue that the three key parameters of "authenticity, balance and challenge" shape and shift through a woman's professional life span recognising the relational aspect of womens' careers as well as placing the issue of gender at the forefront of the analysis. While the model focuses on a "woman's professional life," it may also be an appropriate framework to further explore the career and life development issues older women workers who opt out of employment .

\section{Self -Initiated Foreign Experiences}

Within a range of alternatives, it is evident that some older women are choosing to abandon the normative and more visible masculine career trajectory, by undertaking a 'foreign experience.' (Hoffart, 2006, Hepozen, 2008, Shepherd, 2008) This experience is referred to in the careers literature as self initiated foreign experience (SFE), a period of autonomous travel and work in another country that is usually conceptualised as a more youthful and carefree endeavour (Suutari \& Brewster, 2000; Inkson \& Myers 2003; Vance, 2003). While 
corporate expatriation is now well researched in the international careers literature (Brewster 1991; Sutaari \& Brewster 1998, 2000; Inkson, Arthur, Pringle \& Barry 1997) the phenomenon of 'self-initiated foreign experience' (SFE) is less well understood. In the past, prospective employees returning home from a SFE were often regarded by employers as lacking in career focus, commitment and career capital (Myers \& Inkson 2003). However, there is a nascent careers literature on these experiences that challenges this populist view. More specifically it is suggested that career development is a substantial and visible outcome arising from what appears to be a serendipitous experience initially undertaken for personal, social and cultural reasons (Inkson et al, 1997).

Further analysis confirms that SFE provides a vehicle for young women and men to experience not only considerable personal development but also recognisable career development (Myers \& Inkson 2003). Surprisingly this research also suggests that women's propensity to seek a more safe travel and work environment while on SFE gave them a broader and more integrated career experience when compared to men (Myers \& Pringle, 2005). While current research is limited to younger workers, the author suggests that this body of research may be of relevance when exploring the motivations, experiences and outcomes of SFEs undertaken by older women workers.

\section{Other Relevant Theory}

The models and frameworks outlined above are positioned within the careers literature. However there are a number of other related bodies of literature that are suggested for further exploration. Tourism research contributes to developing an alternative understanding of SFE in a New Zealand context. Mason (2002) argues that 'OE', is often motivated by the desire 'to break out' while earlier research by Jamieson (1996 cited in Mason, 2002) suggests four key motivators: freedom from commitments in the home country, adventure, acceptance of temporary hardship and casual labour. Bell (2002) further suggests that 'OE' is a type of secular pilgrimage and a rite of passage (Mason 2002,). While the concept of a rite of passage has been applied to traditional career models, Mayrehofer (2005) suggests that it is an equally useful model to consider the unpredictable career transitions of contemporary careers.

A constructivist look at life roles (Brott, 2005; Savickas, 2002; Hartung and Taber, 2008) explores how people use work as a means of developing a sense of self completion in their lives ie develop a level of subjective wellbeing. While this framework is utilised for career assessment and career intervention strategies it also considers levels of satisfaction, meaning, happiness that may be of relevance to developing an understanding of older women workers in transition from work to non work.
The literature of personal meaning is underpinned by a general acceptance that achieving personal meaning is more than just striving to achieve contentment or happiness. Understanding what people feel is most meaningful in their lives has been conceptualised in a number of models. DeVogler and Ebersole (1980) theorise eight sources of meaning, Fiske and Chiriboga (1991) identify seven life goals while a range of studies suggest that there are levels of meaning, the highest of which is abstract and transcending self interest. (Frankl 1963; Baumeister, 1991). More specific studies on older women and their values and sources of meaning in life suggest that the older women have a strong need to search for independence, strength and autonomy and consequently achieve a greater psychological wellbeing, than their male counterparts (Dior, 1990) and higher levels of assertiveness, satisfaction, purpose and happiness than younger cohorts.

\section{Conclusion}

Case study observations suggest that many individual older women workers faced with expectations to continue paid work into their 60 s and 70 s, are seeking alternative life paths (Handy \& Handy, 2002) when population ageing and labour market imperatives suggest that they will be recruited and retained in increasing numbers.

More recent research argues that older workers are not a homogenous group and if predicted labour market shortages are to be addressed then the focus of research needs to shift from an emphasis on policy and practice to addressing employer concerns and developing an understanding of individual older workers in terms of their experiences and expectations.

This paper considers a cohort of older women workers who appear to be challenging the traditional male norm of continuous careers by voluntarily withdrawing from the labour market. What drives these older women workers to take such action? What meanings do they seek and what outcomes if any, do they expect? Is this an adventure, a fleeting trend, an exceptional and limited phenomenon or is this a radical shift in women's way of being, a new and emerging strand of life development and career theory? While a range of models, frameworks and theories are explored, the author suggests that current theory does not provide a comprehensive framework to understand the individual experiences of this new generation of older women workers "opting out."

\section{Future Research}

In order to better understand this new generation of older workers the author plans an in depth study of 35 older women workers who have returned from a SFE. It is anticipated that this study will provide a more comprehensive understanding of individual experiences 
and contribute to the gap in the literature on careers and personal development.

A similar study of older male workers is recommended.

The author suggests further research on predicted labour market skill shortages in light of the changing economic climate.

Research on flexible work practices, job sharing and phased retirement is recommended to better understand the transitional phases of later working life.

\section{References}

Alpas, F., \& Mortimor, R. (2006). Ageing workforce and ageing population. A discussion paper. Department of labour.

Arthur, M.B. (Ed.) (1994). Special Issue: The boundaryless career. Journal of Organisational Behavior_15 (4): 295-381.

Arthur, M.B., \& Rousseau, D.M. (Eds.). (1996). The Boundaryless Career: A New Employment Principle for a New Organizational Era. New York: Oxford University Press.

Atkinson, J., \& Dewson, S. (2003). Evaluation of the New deal 50plus: Research with individuals. London DWP.

Bardwick, J. (1980). The season's of a woman's life", in McGuigan, D. (Ed.), Women's Lives: New Theory, Research \& Policy, University of Michigan, Ann Arbor, MI, pp.35-57.

Baumeister, R.F. (1991). Meanings of Life. The Guilford Press, New York.

Bell, C. (2002). The big 'OE'" Young New Zealand travellers as secular pilgrims. Tourism Studies, 2 (2): 143-158.

Boston, J., \& Davey, J. A. (2006). Implications of Population Ageing: Opportunities and Risks. Wellington: Milne,

Brewster, C. (1991). The management of expatriates, London: Kogan Page.

Brott., P.E. (2005). A Constructivist Look at Life Roles. The Career Development Quarterly, 54, (2), 138150.

Chodorow, N. (1976). The Reproduction of mothering, University of California Press, Berkeley, CA.
Davey, J. (2006). The Labour Market. In J. Boston \& J. Davey, (Eds.), Implications of Population Ageing: Opportunities and Risks. Wellington: Milne.

Department of Labour (2006), 45 Plus: Choices in the labour market. November.

Department of Labour (2007). Older workers labour markets. Outcomes at a glance.

De Jong, A.H. \& Eding, H. (2000). Trends in the Labour market in the European Union. ,Maandstatistiek van de Bevolking 10, pp 9-16.

DeVogler, K.L., \& Ebersole, P. (1980). Categorization of college students' meaning of life. Psychological Reports, 46, 387-390.

Dior, S. (1990). Midlife Transitions. Men and Women. Unpublished Doctoral Thesis. Department of Psychology, Bar Ilan University, Ramat Gan, Israel.

Drake International. (2005). The Age Chasm. Auckland: Drake.

Dunstan, K. \& Thomson, N. (2006). Demographic Trends. In J. Boston \& J. Davey, Eds.), Implications of Population Ageing: Opportunities and Risks. Wellington: Milne.

Drew, M. \& Drew, J. (2005). The Process of Participation and Phased Retirement: Evidence from Mature-Aged Workers in Australia. Post Pressed, Brisbane.

Erickson, E.H. (1968). Identity; Youth and crisis. W.W.Norton: New York, NY.

Erickson, E.H. (1980). Identity and the Life cycle. New York, NY: Norton.

Everard, K., Lach, H., Fisher, E. \& Baum, M. (2000). Relationships of activity and social support to the functional health of mature adults. Journal of gerontology Series B: Psychological Sciences and Social Sciences, 55, 208-212.

Fiske, M., \& Chiriboga, D.A. (1991). Change and Continuity in Adult Life. Jossy-Bass Publishers, San Francisco.

Fondas, N. (1996). Feminization at work: career implications, in Arthur, M.B. and Rousseau, D.M. (eds) The Boundaryless Career, Oxford University Press, New York, NY, pp.282-93.

Frankl, V.E. (1963). Man's Search for Meaning. Washington Square Press, New York. 
Gibson, D.E., \& Barron, L. (2003). Exploring the impact of role models on older employees. Career Development International, 8 (4), 198-209

Gray, L., \& McGregor, J. (2003). Human resource development and older workers: Stereotypes in New Zealand. Asia Pacific Journal of Human Resource Management, 41 (3), 338-353

Gallos, J. (1989). Exploring woman's development: implications for career theory, practice and research.,.110-132 in M.B. Arthur, D.T. Hall, \& B.S. Lawrence (Eds.), Handbook of career theory. Cambridge, MA: Cambridge University Press.

Giele, J.Z. (1980). Crossovers: new themes in adult roles and the life cycle, in D. McGuigan (Ed.) Women's lives: New theory, Research \& policy. University of Michigan, Ann Arbor, MI, 17-33.

Gruen, D., \& Garbutt, M. (2003). The output implications of higher labour force participation. Australian Treasury department, Treasury Working Paper 2002-03, October.

Gutek, B., \& Larwood, L. (1987). Women's Career Development. Sage, Newbury Park, CA.

Hall, D.T. (1996). The Career is Dead: Long Live the Career. San Francisco, CA.: Jossey-Bass.

Handy, C., \& Handy, E. (2002). Reinvented Lives. Women at Sixty: A Celebration. London. Hutchinson.

Hartung, P.J., \& Taber, B.J. (2008). Career Construction and Subjective Wellbeing. Journal of Career Assessment, 16, (1), 75-85.

Hoffart, S. (2006, August). Under the Tuscan Sun. Next Magazine.

Hepozden, R. (2008). Over-Age and Over There. North and South (May, 2008)

Henkens, K., Remery, C. \& Schippers, J. (2008). Shortages in an ageing labour market: an analysis of employers' behaviour. The International Journal of Human Resource Management 19 (7) p 1314-1329.

Hirsch, D. (2003). Crossroads after 50: Improving choices in work and retirement, York: Joseph Rowntree Foundation.

Inkson, K., Arthur, M., Pringle, J.K. \& Barry, S. (1997). Expatriate assignment versus overseas experience: Contrasting models of international human resource development. Journal of World Business, 32 (4), 351-368.
Inkson, K. \& Myers, B. (2003). "The big OE": Self directed travel and career development. Career Development International, 8 (4): 170-181.

Knowles, M. (1981). The Adult Learner: a neglected species. $2^{\text {nd }}$ edition. Houston: Gulf Publishing.

Levinson, D., Darrow, C.N., Klein, E.B., Levinson, M.H., \& McKee, B. (1978). The Seasons of a Man's Life. Ballantine Books: New York, NY.

Levinson, D., \& Levinson, M.H. (1996). The Seasons of a Woman's Life. Knopf: New York, NY.

Loretto, W., \& White, P. (2006). Employers' attitudes, practices and policies towards older workers. Human resource management Journal, 16(3), 313-330.

Lyon, P., Hallier, J., \& Glover, I. (1998). Divestment or investment? The contradictions of HRM in relation to mature employees. Human resource Management Journal, 8, 56-66.

Maniero, L.A., \& Sullivan, S.E. (2005). Kaleidoscope careers: An alternative explanation of the "opt out" revolution. Academy of Management Executive, 19, 106-123.

Mason, P. (2002). The big OE: New Zealanders' overseas experience in Britain. Pp. 87-101 in C.M. Hall \& A.M. Williams (Eds.), Tourism and migration. Netherlands: Kluwer Academic Publishers.

Mayrehofer, W., \& Iellatchitch, A. (2005). Rites, right? The value of rites de passage for dealing with today's career transitions. Career Development International, 10 (1), 52-66.

Marshall, J. (1989). "Re-visioning career concepts: a feminist invitation", in M. Arthur, T. Hall \& B. Lawrence (Eds.) Handbook of career Theory. Cambridge University Press, Cambridge, MA, 275-91

McGregor, J. (2007). Employment of Older Workers. Retirement Commissioner's 2007 review of retirement income policy. Human Rights Commission.

McGregor, J., \& Gray, L. (2001). Mature Job Seekers in New Zealand. Palmerston North: Massey University.

Mirvis, P.H. \& Hall, D.T. (1996). Career development for the older worker. In D.T. Hall, (Ed.), The Career is Dead: Long Live the Career. San Francisco, CA.: Jossey-Bass. 
Minichiello, V., Aroni, R., Timewell, E., \& Alexander, L. (1995). In-Depth Interviewing. Melbourne, Longman.

Morrow-Howell, N. (2000). Productive Engagement of Mature Adults: Effects on Well-being, Centre for Social development, Washington University, St Louis.

Myers, B., \& Inkson K. (2003). The big OE.: How it works and what it can do for New Zealand. University of Auckland Business Review, 5 (1): 44-54.

Myers, B., \& Pringle, J. (2005). Self initiated foreign experiences as accelerated development: Influences of gender. Journal of World Business, 40 (4), 421-431.

Myers, B. (2001). The lives and work experiences of older workers: Across the great divide? Paper presented at ANZAM conference, December 5-8). Auckland, New Zealand.

OECD (2001). Ageing and Income-Financial Resources and Retirement in 9 OECD Countries OECD, Paris.

Onyx, J. (1998). Older Women Workers: A Double Jeopardy? In Patrickson, M and Hartmann, L 1998 (eds) Managing an Ageing Workforce. NSW Australia.

Patrickson, M., \& Hartmann, L. (1995). Australia's ageing population: implications for human resource management. International Journal of Manpower, 16(5): 34-46.

Patrickson, M., \& Hartmann, L. (1996). Australian gender differences in preferences for early retirement. International Employment Relations Review, 2(1): 1-19.

Patrickson, M \& Hartmann, L. (1998). (Eds.) Managing an Ageing Workforce. NSW Australia.

Peiperl, M., \& Baruch,Y. (1997). "Back to square zero: the post-corporate career". Organizational Dynamics, Vol, Spring, pp. 7-22.

Pringle, J.K., \& McCulloch-Dixon, K. (2003). Reincarnating life in the careers of women. Career Development International, 8 (6), 291300.

Pringle, J., Mallon, M. (2003) Challenges for the boundaryless career odyssey. International Journal of Human Resource Management 14:5 839-853
Productivity Commission. (2005). Economic Implications of an Ageing Australia, Final research Report, Productivity Commission, Canberra.

Savakas, M.L. (2002). Reinvigorating the Study of Careers. Journal of Vocational Behaviour, 61, 381-385.

Shepherd, N. (2008). Mid-lifers lured by O.E. New Zealand Herald 29/6/08

Steinberg, M., Walley, L., Tyman, R., Donald, K. (1998). Too Old To Work? In Patrickson, $\mathbf{M}$ and Hartmann, L 1998 (eds) Managing an Ageing Workforce. NSW Australia.

Sterns, H.L. \& McDaniel, M.A. (1994). In S.E. Rix, (Ed.), Older Workers: How Do They Measure Up? Washington, DC: American Association of Retired Persons.

Sterns, H.L., \& Miklos, S. (1995). The aging worker in a changing environment: Organizational and individual Issues, Journal of Vocational Behaviour. 47, 248-268.

Suutari, V., \& Brewster, C. (1998). Expatriate management practices and their perceived relevance: Evidence from Finish Companies. Discussion papers 247. Vaasa: University of Vaasa.

Suutari, V., \& Brewster, C. (2000). Making their own way: International experience through selfinitiated foreign assignments. Journal of World Business, 35 (4): 417-436.

Super, D.E. (1957). The Psychology of Careers. Harper, New York, NY.

Super, D.E. (1992). Towards a comprehensive theory of career development. In DH Montross and CJ Shinkman (Eds.) Career Development: theory and practice._Springfield, Ill., CC Thomas

Taylor, P. (2003). Mature workers, employer behaviour and public policy. Geneva Papers on Risk and Insurance, 28, 553-557.

Taylor, P., \& Walker, A. (1994). The ageing workforce; employers' attitudes towards mature people. Work, Employment and Society, 8, 569591.

Taylor, P., \& Walker, A. (1997). Age discrimination and public policy. Personnel Review, 26, 307-318.

Taylor, P., \& Walker, A. (2003). Age Discrimination in the labor market and policy responses: the 
situation in the United Kingdom, The Geneva papers on Risk and Insurance.

Taylor, P., \& Unwin, P. (2001). Age and participation in vocational education. Work, Employment and Society, 15, 763-779.

Thomson, D. (1999). Our Ageing Workforce-benefit or burden", University of Auckland Winter Lecture Series.

Turner, G. (2000). The value of the Older Worker: a guide to employing the older worker. Lower Hutt: Open polytechnic.

Umberson, D., Chen, M., House, J., Hopkins, K. \& Slaten, E. (1996). The effect of social relationships on psychological well-being: Are men and women really so different? American Sociological Review, 61 (5): 837-857.

Vance, C. (2003, August). A field-based analysis of self-initiating international career path strategies: Exploring similarities and differences across gender. Paper presented at Academy of Management Symposium, Seattle.

Vickerstaff, S., Cox, J., \& Keen, L. (2004). Employers and the management of retirement. Social Policy and Administration, 37, 23, 271-287.

Warr, P. (1994). Age and job performance. In J. Suel \& R. Cremer (Eds.), Work and Ageing: a European perspective. London: Taylor Francis.

Whiting, E. (2005). The labour market participation of older people. Labour market Trends, 109, 7, 285296.

Wood, M. (2000). The move towards a different career pattern: Are women better prepared than men for a modern career? Career Development International, 5 (2), 21-28.

\author{
Author \\ Barbara Myers \\ Senior Research Lecturer \\ School of Business - Business Interdisciplinary Studies \\ Auckland University of Technology \\ Private Bag 92006 \\ Auckland 1142 \\ Barbara.Myers@aut.ac.nz
}

